\title{
Reduction of teat skin mastitis pathogen loads: Differences between strains, dips, and contact times
}

\author{
B. D. Enger, ${ }^{*}$ L. K. Fox,${ }^{*}{ }^{1}$ J. M. Gay, $\dagger$ and K. A. Johnson* \\ *Department of Animal Sciences, and \\ †Department of Veterinary Clinical Sciences, Washington State University, Pullman 99164
}

\begin{abstract}
The purpose of these experiments was to (1) assess differences in mastitis pathogen strain sensitivities to teat disinfectants (teat dips), and (2) determine the optimum time for premilking teat dips to remain in contact with teat skin to reduce pathogen loads on teat skin. Two experiments were conducted using the excised teat model. In experiment 1, the differences in mastitis pathogen strain sensitivities to 4 commercially available dips (dip A: $1 \% \mathrm{H}_{2} \mathrm{O}_{2}$; dip B: $1 \%$ chlorine dioxide; dip C: $1 \%$ iodophor; and dip D: $0.5 \%$ iodophor) were evaluated. Four strains of 11 common mastitis pathogens (Staphylococcus aureus, Streptococcus agalactiae, Mycoplasma bovis, Streptococcus dysgalactiae, Streptococcus uberis, Escherichia coli, Staphylococcus chromogenes, Staphylococcus epidermidis, Staphylococcus hyicus, Staphylococcus xylosus, and Staphylococcus haemolyticus) were tested. In experiment 2 , the percentage log reduction of mastitis pathogens (Escherichia coli, Streptococcus uberis, Streptococcus dysgalactiae, Klebsiella species, Staphylococcus chromogenes, Staphylococcus haemolyticus, Staphylococcus xylosus, and Staphylococcus epidermidis) on teat skin with 3 commercially available teat dips: $\operatorname{dip}$ A; $\operatorname{dip}$ D; and dip E: $0.25 \%$ iodophor, using dip contact times of 15,30 , and $45 \mathrm{~s}$, was evaluated. Experiment 1 results indicated significant differences in strain sensitivities to dips within pathogen species: Staphylococcus aureus, Staphylococcus chromogenes, and Streptococcus uberis. Species differences were also found where Mycoplasma bovis (97.9\% $\log$ reduction) was the most sensitive to tested teat dips and Staphylococcus haemolyticus ( $71.4 \%$ log reduction) the most resistant. Experiment 2 results indicated that contact times of 30 and $45 \mathrm{~s}$ were equally effective in reducing recovered bacteria for dips $\mathrm{D}$ and $\mathrm{E}$ and were also significantly more effective than a 15 -s contact
\end{abstract}

Received July 15, 2014.

Accepted October 28, 2014

${ }^{1}$ Corresponding author: fox@wsu.edu time. No differences were seen in recovered bacteria between tested contact times after treatment with dip A. It can be concluded that different mastitis pathogen species and strains within species may possess different sensitivities to teat dips, which may have implications in selection of teat dips on dairies. Furthermore, a 30-s premilking dip contact time for iodophors and $15 \mathrm{~s}$ for $\mathrm{H}_{2} \mathrm{O}_{2}$ dips may be optimal in reducing pathogen load in the shortest amount of time. A reduction in premilking teat dip contact time may improve milking parlor efficiency.

Key words: excised teat model, teat disinfectant, contact time, Mycoplasma bovis

\section{INTRODUCTION}

Teat dips have an important role in reducing the incidence of IMI. Postmilking teat dips have demonstrated efficacy in reducing the incidence of both contagious (Pankey et al., 1985) and opportunistic (Quirk et al., 2012) IMI. Premilking teat dips are effective in reducing the incidence of environmental IMI (Pankey et al., 1987). Contagious pathogens are transmitted from cow to cow, generally within the milking parlor. The opportunistic pathogens are part of the normal flora of the teat skin with the CNS being the primary pathogen group of interest, and the environmental pathogens are found ubiquitously within the environment. A teat dip's effectiveness is not simply dependent upon the concentration of the active ingredient. Therefore, uniform methods for evaluating teat dips have been discussed through the National Mastitis Council; these methods are 1) the natural exposure model, 2) the experimental challenge model, and 3) and the excised teat model (Nickerson, 2001). The excised teat model is used to measure a germicide's ability to reduce viable bacteria on teat skin surfaces as a screening test (Nickerson, 2001). One study used the excised teat model to examine the germicidal activity of 2 postmilking teat dips against multiple strains of contagious and environmental pathogens (Schmidt et al., 1984), and the germicidal activity differed with different strains of pathogens within species. More recently, Azizoglu et al. 
(2013) found that some Staphylococcus aureus strains survived higher concentrations of iodine than others in vitro. The first experiment described herein was designed to determine if strains within species differed in their germicidal sensitivity to disinfectant formulations of 4 commercially available postmilking teat dips using the excised teat model.

Several have suggested that premilking teat dips be allowed to remain in contact with the teat skin for 30 $\mathrm{s}$ before removal and attachment of milking unit (Reneau, 2001; Bray and Shearer, 2012). In contrast, findings of controlled trials reported significant germicidal efficacy against mastitis pathogens with disinfectant contact times of 15 to $20 \mathrm{~s}$ (Galton et al., 1988) and $60 \mathrm{~s}$ (Peters et al., 2000). Longer premilking teat dip contact time with the teat skin potentially could result in reduced milking parlor efficiency as measured by cow throughput. No empirical evidence supports the recommendation that a 30 -s contact time is optimum when considering both pathogen load reduction and milking parlor efficiency. The objective of the second experiment was to determine if the often advocated premilking dip contact time of $30 \mathrm{~s}$ reduced a greater or equal number of noncontagious (environmental and opportunistic) mastitis pathogens than dip contact times of 15 or $45 \mathrm{~s}$.

\section{MATERIALS AND METHODS}

\section{Strain Selection and Purification}

For both experiments 1 and 2, 4 strains per pathogen species were randomly selected from the Washington State Mastitis Laboratory culture collection based on the following criteria. Strains were of bovine origin and from milk of cows with IMI. Contagious pathogen strains were from geographically isolated herds. Noncontagious pathogen strains were from geographically isolated herds or collected at least one year apart if from the same herd with the exception of the Klebsiella species. Two Klebsiella species strains were collected 9 mo apart from the same herd. Bacterial strains were purified by streaking for isolation on Colombia Blood agar (CBA; Hardy Diagnostics, Santa Maria, CA) and in the case of Mycoplasma bovis, purification was obtained using the filter cloning technique (Boonyayatra, 2010). Strains of the genus Klebsiella were not speciated but were identified at the genus level after isolation from MacConkey agar (Hardy Diagnostics) using Simmons Citrate agar and Motility agar (Hardy Diagnostics; Hogan et al., 1999). Purified strains were stored at $-85^{\circ} \mathrm{C}$ and defrosted at ambient temperature when needed.

\section{Bacterial Challenge Suspension}

All bacterial species except Mycoplasma bovis were grown in brain-heart infusion broth (Becton, Dickinson and Company, Franklin Lakes, NJ) at $37^{\circ} \mathrm{C}$. Mycoplasma bovis was grown in modified pleuropneumonialike organism broth (Hardy Diagnostics) at $37^{\circ} \mathrm{C}$ with $10 \%$ atmospheric $\mathrm{CO}_{2}$. All bacterial strains grown in brain heart infusion broth were arrested in logarithmic growth at $4 \mathrm{~h}$ and Mycoplasma bovis strains at $72 \mathrm{~h}$ of incubation. Cultures were centrifuged at 3,000 $\times g$ for $20 \mathrm{~min}$ at $5^{\circ} \mathrm{C}$ except for Mycoplasma bovis, which was centrifuged at $4,500 \times g$ for $30 \mathrm{~min}$ at $23^{\circ} \mathrm{C}$. Pellets were resuspended in phosphate-buffered sterile saline (PBSS), washed 2 times, and resuspended with PBSS. Cultures were adjusted to an optical density corresponding to approximately $1 \times 10^{8} \mathrm{cfu} / \mathrm{mL}$. Standardized samples were plated to confirm concentration and diluted at a factor of 1:10 into prepared sterile skim milk (Becton, Dickinson and Company), yielding a suspension of approximately $1 \times 10^{7} \mathrm{cfu} / \mathrm{mL}$.

\section{Experiment 1}

The excised teat model was used to test strain variation response to 4 different teat dips as previously described by Philpot et al. (1978). Three contagious pathogens (Staphylococcus aureus, Streptococcus agalactiae, and Mycoplasma bovis), 3 environmental pathogens (Streptococcus dysgalactiae, Streptococcus uberis, and Escherichia coli), and 5 opportunistic pathogens (Staphylococcus chromogenes, Staphylococcus epidermidis, Staphylococcus hyicus, Staphylococcus xylosus, and Staphylococcus haemolyticus) were tested. Four strains per species were used as previous investigators observed differences utilizing 3 strains (Schmidt et al., 1984). All 4 strains of a bacterial species were tested on the same day. In brief, teats were collected from a commercial abattoir in June 2013 over the course of a week, frozen at $-15^{\circ} \mathrm{C}$, transported to the laboratory, and defrosted as needed at ambient temperature. Teats with a teatend and skin score of $\leq 2$ (Goldberg et al., 1994) were washed in mild detergent, rinsed with sterile water, dried, and marked with a felt-tip pen at depths 15 and $30 \mathrm{~mm}$ from the teat end. Teats were hung from a horizontal dowel rod, dipped with $70 \%$ isopropyl alcohol, and allowed to dry. In duplicate, teats were dipped to a depth of $15 \mathrm{~mm}$ with prepared bacterial challenge suspension and allowed to dry for $5 \mathrm{~min}$. Teats were then dipped with $15 \mathrm{~mL}$ of fresh teat dip to a depth of 30 $\mathrm{mm}$. Four commercially available teat dips (Thatcher Company, Salt Lake City, UT) were used: dip A: TProx a $1 \% \mathrm{H}_{2} \mathrm{O}_{2}$ dip; dip B: Cloguard $\mathrm{H} 1$ a $1 \%$ chlorine 
dioxide dip; dip C: Magnum a 1\% iodophor; and dip D: T-505, a $0.5 \%$ iodophor. Teat dips remained on teat skin for $10 \mathrm{~min}$ and teats were rinsed with $10 \mathrm{~mL}$ of Letheen (Becton, Dickinson and Company) 1\% thiosulfate quench solution (Philpot et al., 1978) using a sterile 16-gauge needle fitted on a sterile syringe. A duplicate control was used for each strain, being dipped with the challenge solution but not with test teat dip. Rinse was collected in sterile $50-\mathrm{mL}$ centrifuge tubes and refrigerated. Rinse from teats treated with dips $\mathrm{B}, \mathrm{C}$, and D was not serially diluted but plated using both $1 \mathrm{~mL}$ and $0.1 \mathrm{~mL} /$ plate for each collected rinse solution. Rinse from dip-A-treated teats was plated directly on agar using a $0.1-\mathrm{mL}$ aliquot of rinse solution and a second aliquot was diluted with PBSS 1:10 and $0.1 \mathrm{~mL}$ of the dilution plated. Rinse from control teats were plated at dilution factors of 1:1,000 and 1:10,000 for each rinse solution. All rinse solutions were plated on CBA except rinse collected from Mycoplasma bovis challenged teats, which was instead plated on modified Hayflick's agar. Colombia blood agar plates were incubated at $37^{\circ} \mathrm{C}$ for 18 to $48 \mathrm{~h}$ and modified Hayflick's agar at $37^{\circ} \mathrm{C}$ with $10 \%$ atmospheric $\mathrm{CO}_{2}$ for $10 \mathrm{~d}$. Colonies on CBA were visually enumerated and colonies on modified Hayflick's agar were enumerated at $15 \times$ using a stereomicroscope (Biddle et al., 2003). Plates yielding between 20 and $200 \mathrm{cfu}$ were selected from the duplicate plating and used as the representative number of organisms recovered from the respective teat. Counts were $\log _{10}$ transformed.

\section{Experiment 2}

The excised teat model was used to evaluate dip contact times for 3 different teat dips as previously described by Philpot et al. (1978). Four environmental pathogens (E. coli, Strep. uberis, Strep. dysgalactiae, and Klebsiella species), and 4 opportunistic pathogens (Staph. chromogenes, Staph. haemolyticus, Staph. xylosus, and Staph. epidermidis) were tested. Four strains were used for each species. Selected teat dips were dip A: T-Prox a $1 \% \mathrm{H}_{2} \mathrm{O}_{2}$ dip, dip D: T-505 a $0.5 \%$ iodophor (Thatcher Company); and dip E: DellaCare Enhanced, a $0.25 \%$ iodophor (DeLaval, Kansas City, $\mathrm{MO})$. A sample size calculation was done to detect a $0.5 \log _{10}$ difference in concentration of bacteria as effected by treatment (Minitab 17, Minitab Inc., State College, PA) using variance data from experiment 1 (power $=0.80, \alpha=0.05$ ). Disinfectant contact times of 15,30 , or 45 s were tested.

Excised teats were collected in November 2013 over $1 \mathrm{wk}$ from a commercial abattoir, frozen at $-15^{\circ} \mathrm{C}$, and shipped overnight to the laboratory. Teats were defrosted, placed into small bags, and refrozen at $-15^{\circ} \mathrm{C}$ upon arrival. The preparation of teats was as described for experiment 1. Strain was used as the unit of replication for each treatment and each tested contact time utilized a control that was unique to each tested strain. The teat challenge protocol was the same as experiment 1 through dipping the teats with $15 \mathrm{~mL}$ of fresh teat dip. After dip remained on teat skin for prescribed test contact times, they were rinsed with $10 \mathrm{~mL}$ of Letheen (Becton, Dickinson and Company) 1\% thiosulfate quench (Philpot et al., 1978) that was collected into sterile $50-\mathrm{mL}$ tubes and refrigerated as previously described. A $0.1-\mathrm{mL}$ aliquot of the rinse solution from dips $\mathrm{D}$ and $\mathrm{E}$ was plated directly to agar. A second aliquot was diluted with PBSS 1:10 and $0.1 \mathrm{~mL}$ of the dilution was plated on agar. Rinse solutions from dipA-treated teats were plated at dilutions of 1:100 and 1:1,000 per plate. Plating of rinse solution from control teats was done as described for experiment 1. Incubation and enumeration of colonies were as described for experiment 1 . Counts were $\log _{10}$ transformed.

\section{Statistical Analysis}

Teat dip efficacy was defined as the percentage $\log _{10}$ reduction from the undipped negative control (Schmidt et al., 1984). Data were analyzed using SAS 9.4 (SAS Institute Inc., Cary, NC). The Proc Mixed procedure was used for initial analysis and multiple comparisons were performed using Fisher's least significant difference test. Output was sorted using a Proc Mixed macro (Saxton, 1998). Six models were used.

Experiment 1. A first model was used to determine if use of dips A, B, C, or D, significantly reduced the $\log$ number of bacteria recovered from teat skin versus the undipped control. Recovered log cfu was the dependent variable. Treatment; dips A, B, C, D, and control $(\mathrm{n}=5)$; and species $(\mathrm{n}=11)$ were the independent variables and considered fixed effects. A second model was used to determine if the percentage log reduction of bacteria was different between species, bacterial strain nested within species, treatment, and their interactions. Dependent variable was percentage log reduction and the independent variables were species of mastitis pathogen (species; $n=11$ ), strain of bacteria (strain; $\mathrm{n}=4$ ), and treatment with test disinfectant (dip; $\mathrm{n}=$ 4). All independent variables were fixed effects. A third model was developed to examine differences between mastitis pathogen groups (contagious, environmental, and opportunistic) and tested disinfectants. The dependent variable was percentage log reduction and the independent variables were pathogen groups $(\mathrm{n}=3)$ and test disinfectants $(\mathrm{n}=4)$, both fixed effects.

Experiment 2. A first model was used to determine if treatments, disinfecting inoculated teats with dips 
A, D, and E, reduced a significant number of log cfu bacteria from teat skin compared with the untreated control. Log cfu was the dependent variable, and treatments $(\mathrm{n}=3)$ and species $(\mathrm{n}=8)$ were the independent variables, both fixed effects. A second model was used to determine if significant differences in the dependent variable, percentage log reduction of bacteria from undipped control, existed between the independent variables, tested contact times (contact time; $\mathrm{n}$ $=3$ ), mastitis pathogen species (species; $\mathrm{n}=8$ ), test disinfectants (dip; $\mathrm{n}=3$ ), and their interactions. All were fixed effects. A third model was used to determine if the percentage log reduction of treatments differed significantly between the 2 mastitis pathogen groups, environmental and opportunistic, and test disinfectants $(\mathrm{n}=3)$. Dip and pathogen group were fixed effects.

\section{RESULTS}

\section{Experiment 1}

A total of 436 samples were collected and used for data analysis across all treatment and control teats. Significant differences in recovered $\log$ cfu between treatments (control, dips A, B, C, and D; $P<0.0001$ ) were detected. Dips A, B, C, and D each significantly reduced recovered $\log _{10}$ cfu number when contrasted with undipped control $(P<0.0001)$ where treatments of all 4 dips and controls resulted in recovered $\log _{10} \mathrm{cfu} /$ $\mathrm{mL}$ of bacteria of $2.26,0.35,0.23,0.44$, and $4.82(\mathrm{SE} \pm$ $0.06)$, respectively.

Bacterial species mean percentage log reductions achieved by dips were contrasted and summarized in Table 1. Significant differences in percentage log reductions were detected between bacterial species, between dips, and an interaction between dip and species $(P<$ 0.05). Mycoplasma bovis, $97.9 \%$ log reduction, was the species most sensitive to tested dips and Staph. haemolyticus was the most resistant, with a $71.4 \%$ log reduction. Significant differences in the reduction of bacteria recovered between strains within species (Staph. aureus, Staph. chromogenes, and Strep. uberis) were also found (data not shown; $P<0.05$ ). Mean percentage log reductions in bacteria recovered contrasted by dip and species are summarized in Table 2. Dip A was the least efficacious dip, effecting an overall mean of $52.9 \% \mathrm{log}$ reduction, significantly different from dips $\mathrm{B}, \mathrm{C}$, and $\mathrm{D}$ $(P<0.05)$. Dip $\mathrm{C}$ achieved the largest percentage log reduction, $95.1 \%$, which was significantly different from dip D, $90.9 \% \log$ reduction $(P<0.05)$ but not from dip B, 92.9\% $(P>0.05)$. Percentage log reductions of dip $\mathrm{B}$ and $\mathrm{C}$ were not significantly different $(P>0.05)$. Pathogens tended to be uniformly sensitive to dips B, C, and D. However, Staph. aureus was more resistant
Table 1. Mean percentage log reduction ${ }^{1}$ across all strains and teat disinfectants within mastitis pathogen species

\begin{tabular}{lc}
\hline Species & $\begin{array}{c}\% \log \\
\text { reduction }\end{array}$ \\
\hline Mycoplasma bovis & $97.9^{\mathrm{A}}$ \\
Streptococcus dysgalactiae & $87.8^{\mathrm{B}}$ \\
Staphylococcus hyicus & $85.3^{\mathrm{BC}}$ \\
Staphylococcus aureus & $83.7^{\mathrm{BCD}}$ \\
Streptococcus agalactiae & $83.7^{\mathrm{BCD}}$ \\
Staphylococcus chromogenes & $82.2^{\mathrm{CD}}$ \\
Staphylococcus epidermidis & $81.8^{\mathrm{CD}}$ \\
Staphylococcus xylosus & $80.8^{\mathrm{CD}}$ \\
Streptococcus uberis & $78.9^{\mathrm{D}}$ \\
Escherichia coli & $78.8^{\mathrm{D}}$ \\
Staphylococcus haemolyticus & $71.4^{\mathrm{E}}$ \\
\hline A-E Percentage log ${ }_{10}$ reductions not sharing the same superscript were \\
significantly different $(P<0.05)$. & \\
${ }^{1}$ Percentage of log se $_{10}$ cfu recovered from teats treated with test disinfec- \\
tants relative to untreated control teats. \\
${ }^{2}$ The largest observed standard error of the means was \pm 2.0.
\end{tabular}

to dips B and D than dip C $(P<0.05)$ and Staph. xylosus was more resistant to dip D than dips B and C $(P<0.05)$. Dips were not significantly different in their efficacy against $M$. bovis $(P>0.05)$.

Across all dips, the percentage log reduction of contagious mastitis pathogens averaged $88.4 \%$, which is significantly different from the reduction of environmental pathogens, $81.8 \%$, and CNS, $80.0 \%(P<0.05)$. The mean percentage log reduction of environmental pathogens as compared with CNS did not differ $(P>$ $0.05)$.

\section{Experiment 2}

A total of 381 samples were collected and used for data analysis across all treatment and control teats. The first model indicated significant differences in recovered $\log$ cfu between treatments as dips A, D, and $\mathrm{E}$, significantly reduced numbers of recovered log cfu as contrasted with undipped control $(P<0.0001)$. The number of recovered bacteria after treatment with dips A, D, E, and from controls, were 3.68, 3.00, 3.30, and $5.01 \log _{10} \mathrm{cfu} / \mathrm{mL}(\mathrm{SE} \pm 0.04)$. The range in reductions of recovered bacteria was 1.3 to $2.0 \log _{10} \mathrm{cfu} / \mathrm{mL}$.

Significant differences were detected in percentage log reduction between bacterial species, which are contrasted and summarized in Table 3. Percentage log reductions of strains of the genus Klebsiella were greatest across all test dips and Staph. chromogenes strains were the most resistant to the germicidal activity of the test dips. Significant differences were detected between test dips, between contact times, and an interaction between species and dip in the dependent variable percentage $\log$ reduction $(P<0.05)$. The interactive term species by contact time was not significant $(P>0.05)$. Mean 
Table 2. $\log$ reductions ${ }^{1}$ and percentage $\log$ reductions ${ }^{2}$ within each mastitis pathogen species across test disinfectants ${ }^{3}$

\begin{tabular}{|c|c|c|c|c|c|c|c|c|}
\hline \multirow[b]{2}{*}{ Species } & \multicolumn{2}{|c|}{ Dip A } & \multicolumn{2}{|c|}{ Dip B } & \multicolumn{2}{|c|}{ Dip C } & \multicolumn{2}{|c|}{ Dip D } \\
\hline & $\begin{array}{c}\log \\
\text { reduction }\end{array}$ & $\begin{array}{c}\% \log \\
\text { reduction }\end{array}$ & $\begin{array}{c}\text { Log } \\
\text { reduction }\end{array}$ & $\begin{array}{c}\% \log \\
\text { reduction }\end{array}$ & $\begin{array}{c}\log \\
\text { reduction }\end{array}$ & $\begin{array}{l}\% \log \\
\text { reduction }\end{array}$ & $\begin{array}{c}\text { Log } \\
\text { reduction }\end{array}$ & $\begin{array}{l}\% \log \\
\text { reduction }\end{array}$ \\
\hline Staphylococcus aureus & 2.76 & $56.9^{\mathrm{C}}$ & 4.34 & $89.4^{\mathrm{B}}$ & 4.86 & $100^{\mathrm{A}}$ & 4.28 & $88.5^{\mathrm{B}}$ \\
\hline Streptococcus agalactiae & 2.22 & $46.9^{\mathrm{B}}$ & 4.55 & $96.2^{\mathrm{A}}$ & 4.52 & $95.6^{\mathrm{A}}$ & 4.53 & $96.1^{\mathrm{A}}$ \\
\hline Mycoplasma bovis & 4.67 & $91.4^{\mathrm{A}}$ & 5.10 & $100^{\mathrm{A}}$ & 5.10 & $100^{\mathrm{A}}$ & 5.10 & $100^{\mathrm{A}}$ \\
\hline Escherichia coli & 2.04 & $42.4^{\mathrm{B}}$ & 4.54 & $95.2^{\mathrm{A}}$ & 3.99 & $83.9^{\mathrm{A}}$ & 4.47 & $93.9^{\mathrm{A}}$ \\
\hline Streptococcus dysgalactiae & 2.95 & $59.1^{\mathrm{B}}$ & 4.95 & $99.2^{\mathrm{A}}$ & 4.84 & $96.6^{\mathrm{A}}$ & 4.81 & $96.2^{\mathrm{A}}$ \\
\hline Streptococcus uberis & 2.41 & $50.9^{\mathrm{B}}$ & 4.01 & $85.0^{\mathrm{A}}$ & 4.43 & $93.3^{\mathrm{A}}$ & 4.11 & $86.4^{\mathrm{A}}$ \\
\hline Staphylococcus chromogenes & 2.60 & $53.9^{\mathrm{B}}$ & 4.34 & $90.6^{\mathrm{A}}$ & 4.57 & $95.1^{\mathrm{A}}$ & 4.29 & $88.6^{\mathrm{A}}$ \\
\hline Staphylococcus epidermidis & 2.47 & $50.9^{\mathrm{B}}$ & 4.38 & $90.5^{\mathrm{A}}$ & 4.63 & $95.7^{\mathrm{A}}$ & 4.35 & $90.0^{\mathrm{A}}$ \\
\hline Staphylococcus haemolyticus & 1.84 & $37.9^{\mathrm{B}}$ & $\begin{array}{l}4.00 \\
3.96\end{array}$ & $82.1^{\mathrm{A}}$ & 4.25 & $87.1^{\mathrm{A}}$ & 3.81 & $78.3^{\mathrm{A}}$ \\
\hline Staphylococcus hyicus & 2.24 & $47.9^{\mathrm{B}}$ & 4.58 & $97.9^{\mathrm{A}}$ & 4.60 & $98.4^{\mathrm{A}}$ & 4.58 & $96.8^{\mathrm{A}}$ \\
\hline Staphylococcus xylosus & 2.04 & $43.6^{\mathrm{C}}$ & 4.53 & $96.6^{\mathrm{A}}$ & 4.69 & $100^{\mathrm{A}}$ & 3.90 & $83.1^{\mathrm{B}}$ \\
\hline Overall mean ${ }^{5}$ & & $52.9^{\mathrm{C}}$ & & $92.9^{\mathrm{AB}}$ & & $95.1^{\mathrm{A}}$ & & $90.8^{\mathrm{B}}$ \\
\hline
\end{tabular}

\footnotetext{
${ }^{\mathrm{A}-\mathrm{C}}$ Percentage $\log _{10}$ reductions not sharing the same superscript in a row were significantly different $(P<0.05)$

${ }^{1}$ Reduction of $\log _{10}$ cfu recovered from teats treated with test disinfectant relative to untreated control teats.

${ }^{2}$ Percentage of $\log _{10}$ cfu recovered from teats treated with test disinfectants relative to untreated control teats.

${ }^{3}$ Dip $\mathrm{A}=1 \% \mathrm{H}_{2} \mathrm{O}_{2}$, dip $\mathrm{B}=1 \%$ chlorine dioxide, dip $\mathrm{C}=1 \%$ iodophor, and $\operatorname{dip} \mathrm{D}=0.5 \%$ iodophor.

${ }^{4}$ Largest observed standard error of the means was \pm 4.1 .

${ }^{5}$ Largest observed standard error of mean dip effects \pm 1.2 .
}

percentage log reductions stratified by dip and species are summarized in Table 4. Overall, dip D was the most efficacious dip, with a $40.3 \% \log$ reduction, which was a significantly greater reduction than achieved by dip A and $\mathrm{E}(P<0.05)$. Percentage $\log$ bacterial reductions with dip $\mathrm{A}$ and $\mathrm{E}$ were 26.5 and $34.3 \%$, respectively; differences were significant $(P<0.05)$.

The interaction between dip and contact time in reducing recovered bacterial numbers approached significance $(P=0.0561)$ and is summarized in Table 5 . No significant differences in percentage log reduction were seen between tested contact times when teats were treated with dip A $(P>0.05)$. Conversely, for dips D and $\mathrm{E}$, a contact time of $15 \mathrm{~s}$ resulted in a significantly lower bacterial percentage log reduction than contact

Table 3. Mean percentage log reduction ${ }^{1}$ across all contact times and teat disinfectants within mastitis pathogen species

\begin{tabular}{lc}
\hline Species & $\begin{array}{c}\% \log \\
\text { reduction }\end{array}$ \\
\hline Klebsiella spp. & $46.9^{\mathrm{A}}$ \\
Escherichia coli & $38.1^{\mathrm{B}}$ \\
Streptococcus uberis & $36.0^{\mathrm{B}}$ \\
Staphylococcus epidermidis & $35.8^{\mathrm{B}}$ \\
Staphylococcus xylosus & $34.8^{\mathrm{B}}$ \\
Streptococcus dysgalactiae & $29.0^{\mathrm{C}}$ \\
Staphylococcus haemolyticus & $28.8^{\mathrm{C}}$ \\
Staphylococcus chromogenes & $20.3^{\mathrm{D}}$
\end{tabular}

$\overline{\mathrm{A}-\mathrm{D}}$ Percentage $\log _{10}$ reductions not sharing the same superscript were significantly different $(P<0.05)$.

${ }^{1}$ Percentage of $\log _{10}$ cfu recovered from teats treated with test disinfectants relative to untreated control teats.

${ }^{2}$ Largest observed standard error of the means was \pm 1.6 . times of 30 or $45 \mathrm{~s}(P<0.05)$, but no difference was seen between contact times of 30 or $45 \mathrm{~s}(P>0.05)$. Overall, contact times of 15,30 , and $45 \mathrm{~s}$ resulted in mean $\log$ reductions of $30.0,34.1$, and $37.0 \%$, all significantly different $(P<0.05)$.

A significant difference in the percentage log reductions in recovered bacteria between the environmental and CNS-grouped pathogens was detected $(P<0.0001)$. Environmental and CNS-grouped pathogens had overall means of 37.5 and $29.9 \%$ across all tested dips.

\section{DISCUSSION}

\section{Experiment 1}

The results support our hypothesis that bacterial strains would differ in sensitivity within bacterial species when exposed to teat dips. Significant differences in the percentage log reduction between bacterial strains after treatment with dips occurred for 3 of the 11 tested pathogens: Staph. aureus, Staph. chromogenes, and Strep. uberis. These observed differences between bacterial strains are consistent with the findings of Schmidt et al. (1984), where investigators used the excised teat model and observed apparent differences in the number of recovered bacteria between strains of both Staph. aureus and Strep. uberis after exposure to teat dips. Azizoglu et al. (2013) also described sensitivity differences between strains of Staph. aureus when exposed to diluted concentrations of iodine teat disinfectants in vitro. The results align with those of Piessens et al. (2012) where several, but not all, strains of Staph. 
Table 4. $\log$ reductions ${ }^{1}$ and percentage $\log$ reductions ${ }^{2}$ within each mastitis pathogen species across test disinfectants ${ }^{3}$

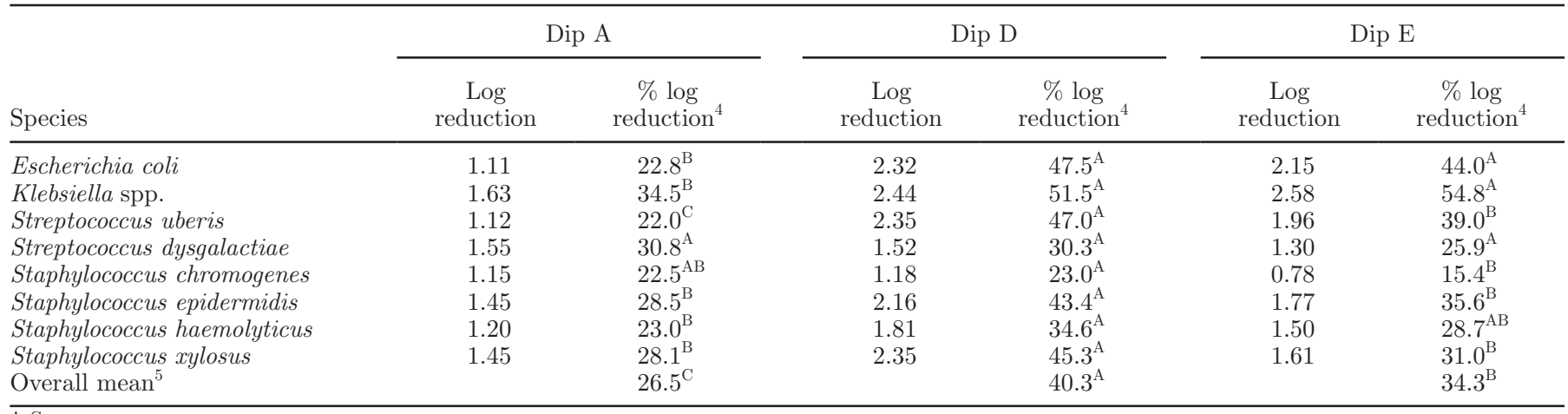

${ }^{\mathrm{A}-\mathrm{C}}$ Percentage $\log _{10}$ reductions not sharing the same superscript in a row were significantly different $(P<0.05)$.

${ }^{1}$ Reduction of $\log _{10}$ cfu recovered from teats treated with test disinfectant relative to untreated control teats.

${ }^{2}$ Percentage of $\log _{10}$ cfu recovered from teats treated with test disinfectants relative to untreated control teats.

${ }^{3}$ Dip $\mathrm{A}=1 \% \mathrm{H}_{2} \mathrm{O}_{2}$, dip $\mathrm{D}=0.5 \%$ iodophor, and dip $\mathrm{E}=0.25 \%$ iodophor.

${ }^{4}$ Largest observed standard error across the 4 tested strains of each species within test disinfectants \pm 2.9 .

${ }^{5}$ Standard error of mean dip effects \pm 1.0 .

chromogenes survived diluted concentrations of iodine and chlorhexidine teat disinfectants in vitro.

Dip A was the least efficacious dip tested. The hydrogen peroxide may have been reacting with the organic material of the teat skin or in the challenge suspension and thus had less germicidal activity. In vivo tests are needed to determine a dip's true efficacy because the excised teat model is an in vitro assay and cannot evaluate efficacy in terms of reducing IMI incidence.

The observed differences in teat dip sensitivities among mastitis pathogens were expected. Many authors have observed similar results both in vitro (Schmidt et al., 1984) and in vivo (Foret et al., 2005; Quirk et al., 2012). The contagious pathogen M. bovis was the most sensitive to tested dips with a $97.9 \%$ log reduction. This high sensitivity agrees with previous findings. Jas-

Table 5. Percentage log reduction ${ }^{1}$ within test disinfectants and test contact time

\begin{tabular}{llll}
\hline & \multicolumn{3}{c}{$\% \log$ reduction } \\
\cline { 2 - 4 } Dip $^{2}$ & $15 \mathrm{~s}$ & $30 \mathrm{~s}$ & $45 \mathrm{~s}$ \\
\hline Dip A & $26.1^{\mathrm{A}}$ & $25.5^{\mathrm{A}}$ & $28.1^{\mathrm{A}}$ \\
Dip D & $36.0^{\mathrm{B}}$ & $41.2^{\mathrm{A}}$ & $43.8^{\mathrm{A}}$ \\
Dip E & $28.0^{\mathrm{B}}$ & $35.7^{\mathrm{A}}$ & $39.2^{\mathrm{A}}$ \\
Overall mean $^{4}$ & $30.0^{\mathrm{C}}$ & $34.1^{\mathrm{B}}$ & $37.0^{\mathrm{A}}$
\end{tabular}

$\overline{\mathrm{A}-\mathrm{C}}$ Percentage $\log _{10}$ reductions not sharing the same superscript in a row were significantly different $(P<0.05)$.

${ }^{1}$ Percentage $\log _{10}$ cfu recovered from teats treated with test disinfectants relative to untreated control teats.

${ }^{2}$ Dip $\mathrm{A}=1 \% \mathrm{H}_{2} \mathrm{O}_{2}$, dip $\mathrm{D}=0.5 \%$ iodophor, and dip $\mathrm{E}=0.25 \%$ iodophor.

${ }^{3}$ Standard error across all tested bacterial strains of each species within test contact time and test disinfectant \pm 1.7 .

${ }^{4}$ Standard error of mean contact time effects \pm 0.1 . per et al. (1976) observed similar results in vivo when cow teats were challenged with $M$. bovis and researchers were unable to recover $M$. bovis from the teat skin after treatment with 3 of 6 tested dips. Boddie et al. (2002) used the excised teat model and was unable to recover single tested strains of $M$. bovis and Mycoplasma californicum after treatment with iodine and chlorhexidine teat dips. It could be concluded that $M$. bovis is extremely sensitive to postmilking teat dips. However, $M$. bovis is increasing in prevalence as an agent of bovine diseases (Kusiluka et al., 2000; Maunsell et al., 2011; Fox, 2012). Increased prevalence of mycoplasma mastitis is occurring despite the fact that disinfecting teats postmilking is widely practiced (USDA-APHIS, 2008). Although $M$. bovis is classified as a contagious mastitis pathogen, hygienic milking procedures that incorporate use of a postmilking teat dip have not been examined in their ability alone to control $M$. bovis on dairies. These procedures have proven effective against the other contagious pathogens Staph. aureus and Strep. agalactiae (Boddie et al., 2004). The fact that $M$. bovis prevalence is increasing despite the widespread use of postmilking teat dips suggest that other transmission pathways may exist for $M$. bovis mastitis.

\section{Experiment 2}

The objective of experiment 2 was to determine if the commonly recommended $30-$ s premilking teat dip contact time reduced a greater or equal number of bacteria than a contact time of 15 or $45 \mathrm{~s}$. Overall, increased contact time increased percentage log reduction, which agrees with the findings of others (Schmidt et al., 1985; Gradle, 2009). A dip by contact time interaction ap- 
peared to exist. No differences were seen between the tested contact times with dip A in pathogen reduction on teat skin $(P>0.05)$. Results would suggest the active ingredient in dip A, hydrogen peroxide, is a fast-acting disinfectant as it is a reactive oxygen species (Remington et al., 2006). No difference in pathogen reduction on teat skin was seen between contact times of 30 and $45 \mathrm{~s}$ for dips D and E. A contact time of 30 and $45 \mathrm{~s}$ significantly reduced the number of bacteria recovered from the teat skin compared with the 15-s contact time for both dips D and E. A contact time of $30 \mathrm{~s}$ appears optimal when using an iodophor, but only $15 \mathrm{~s}$ is needed for hydrogen peroxide dips. Optimal is defined as reaching maximal reduction of teat skin pathogen load in the shortest amount of time.

The milking parlor is the most expensive facility on the dairy and is often the limiting factor in expansion and herd size (Smith et al., 1997). The average US dairy herd size has increased from 19 cows per herd in 1970 (USDA-ERS, 2006) to 196 cows per herd in 2013 (Halladay, 2014). Thus, it is not uncommon for farms to use the milking parlor 21 to $22 \mathrm{~h}$ a day (VanBaale et al., 2004). Increasing parlor efficiency can be achieved by maximizing use of the milking parlor by both increasing the number hours the parlor is used and by increasing the number of animals milked in a given time period. Data presented by Schuring (2007) suggest that premilking teat dip contact time is the most time consuming component of premilking preparation. Thus potential exists for improving milking parlor efficiency by reducing premilking cow preparation time. Decreasing premilking dip contact times could potentially increase the number of cows milked per hour and thus increase parlor efficiency. Results reported herein suggest optimum contact time for iodophor dips and hydrogen peroxide dips may differ and thus the optimum premilking teat dip contact time may be a function of the type of dip used.

The hydrogen peroxide dip, dip A, was least effective in reducing recovered bacteria the number of recovered bacteria from teat skin compared with dips $\mathrm{D}$ and $\mathrm{E}(P$ $<0.05)$. Despite the apparent reduced efficacy of dip A relative to dips $\mathrm{D}$ and $\mathrm{E}$, dip A may possess an advantage. Dip A achieved its maximum efficacy within 15 $\mathrm{s}$ of contact time compared with the tested iodophors at $30 \mathrm{~s}$. Milk iodine residues have been of concern to the dairy industry (Rasmussen et al., 1991) because elevated levels pose a risk to human health (National Institutes of Health, 2014). Hydrogen peroxide is presently not of significant concern to human health and has been used as a dairy preservative (Lück, 1962). Milk possesses catalase (Fox and McSweeney, 1998), an enzyme that degrades hydrogen peroxide to water and oxygen. Amin and Olson (1967) demonstrated that the longer hydrogen peroxide is exposed to milk catalase and peroxidase, the greater its reduction in milk. Dip A significantly reduced teat skin pathogen load, which may or may not be biologically significant when contrasted with dips $\mathrm{D}$ and $\mathrm{E}$ in reducing the incidence of IMI.

\section{CONCLUSIONS}

Variation exists in sensitivity of mastitis pathogen strains to teat dips. Because variation exists, multiple strains of bacteria should be used when testing teat dips because using a single strain may yield biased results. It may be that dairy operations tailor their teat dipping program to counter the differences in strain sensitivities to dips. With respect to the 3 tested premilking teat dip contact times, it can be concluded that a 30-s contact time is optimal when using an iodophor and a 15-s contact time is optimal when utilizing a hydrogen peroxide dip. Reducing unnecessary premilking contact time may potentially increase parlor efficiency and therefore potentially increase the number of animals milked per hour. Improved milking parlor efficiency should have a positive financial effect on the dairy industry.

\section{ACKNOWLEDGMENTS}

The authors acknowledge Valley Beef Inc. (Wendell, ID) for their assistance in collection of the excised teats and Thatcher Company (Salt Lake City, UT) for financial support.

\section{REFERENCES}

Amin, V. M., and N. F. Olson. 1967. Effect of temperature on stability of hydrogen peroxide in milk. J. Dairy Sci. 50:1336-1338.

Azizoglu, R. O., R. Lyman, and K. L. Anderson. 2013. Bovine Staphylococcus aureus: Dose response to iodine and chlorhexidine and effect of iodine challenge on antibiotic susceptibility. J. Dairy Sci. 96:993-999.

Biddle, M. K., L. K. Fox, and D. D. Hancock. 2003. Patterns of mycoplasma shedding in the milk of dairy cows with intramammary mycoplasma infection. J. Am. Vet. Med. Assoc. 223:1163-1166.

Boddie, R. L., W. E. Owens, C. J. Foret, and P. Janowicz. 2004. Efficacy of a $0.1 \%$ iodine teat dip against Staphylococcus aureus and Streptococcus agalactiae during experimental challenge. J. Dairy Sci. 87:3089-3091.

Boddie, R. L., W. E. Owens, C. H. Ray, S. C. Nickerson, and N. T. Boddie. 2002. Germicidal activities of representatives of five different teat dip classes against three bovine Mycoplasma species using a modified excised teat model. J. Dairy Sci. 85:1909-1912.

Boonyayatra, S. 2010. Diagnosis of mycoplasma mastitis: Validation and development. PhD Diss. Washington State University, Pullman.

Bray, D. R., and J. K. Shearer. 2012. Proper milking procedures. Accessed Jan. 25, 2014. https://edis.ifas.ufl.edu/pdffiles/DS/ DS12900.pdf.

Foret, C. J., C. Corbellini, S. Young, and P. Janowicz. 2005. Efficacy of two iodine teat dips based on reduction of naturally occurring new intramammary infections. J. Dairy Sci. 88:426-432. 
Fox, L. K. 2012. Mycoplasma mastitis: Causes, transmission, and control. Vet. Clin. North Am. Food Anim. Pract. 28:225-237.

Fox, P. F., and P. L. H. McSweeney. 1998. Dairy Chemistry and Biochemistry. Springer Science \& Business Media, Philadelphia, PA.

Galton, D. M., L. G. Peterson, and W. G. Merrill. 1988. Evaluation of udder preparations on intramammary infections. J. Dairy Sci. 71:1417-1421.

Goldberg, J. J., A. J. Bramley, P. A. Drechsler, T. C. Hemling, J. L. Jones, J. K. O'Neil, M. Winicov, and J. W. Pankey. 1994 Evaluation of teat conditioning qualities of post-milking teat dips. Page 334 in Natl. Mastitis Council Mtg. Proc., Orlando, FL. Natl. Mastitis Council Inc., Madison, WI.

Gradle, C. 2009. How chlorine bleach compares to a commercially available hydrogen peroxide teat dip. Page 226-227 in Nat. Mastitis Council Annual Mtg. Proc., Charlotte, NC. Nat. Mastitis Council Inc., Madison, WI.

Halladay, D. 2014. Daily milk production is 11,740 pounds per farm. Accessed Apr. 18, 2014. http://www.hoards.com/blog_daily-milkproduction-per-farm.

Hogan, J. S. R. N. González, R. J. Harmon, S. C. Nickerson, S. P. Oliver, J. W. Pankey, and K. L. Smith. 1999. Laboratory Handbook on Bovine Mastitis. Rev. ed. National Mastitis Council Inc., Madison, WI.

Jasper, D., J. Dellinger, and H. Hakanson. 1976. Effectiveness of certain teat dips and sanitizers in vitro and on teat skin against $M y$ coplasma agalactiae ssp. bovis. Cornell Vet. 66:164-171.

Kusiluka, L., B. Ojeniyi, and N. Friis. 2000. Increasing prevalence of Mycoplasma bovis in Danish cattle. Acta Vet. Scand. 41:139-146.

Lück, H. 1962. The use of hydrogen peroxide in milk and dairy products. Page 423-447 in Milk Hygiene: Hygiene in Milk Production, Processing and Distribution. World Health Organization, Genève, Switzerland.

Maunsell, F. P., A. R. Woolums, D. Francoz, R. F. Rosenbusch, D. L. Step, D. J. Wilson, and E. D. Janzen. 2011. Mycoplasma bovis infections in cattle. J. Vet. Intern. Med. 25:772-783.

National Institutes of Health. 2014. Iodine fact sheet for consumers. Accessed Apr. 11, 2014. http://ods.od.nih.gov/factsheets/IodineQuickFacts/.

Nickerson, S. C. 2001. Choosing the best teat dip for mastitis control and milk quality. Pages 43-54 in NMC-PDPW Milk Quality Conference Proceedings. Madison, WI. Natl. Mastitis Council. Inc., Madison, WI.

Pankey, J., E. Wildman, P. Drechsler, and J. Hogan. 1987. Field trial evaluation of premilking teat disinfection. J. Dairy Sci. 70:867872.

Pankey, J., R. L. Boddie, and S. Nickerson. 1985. Efficacy evaluation of two new teat dip formulations under experimental challenge. J. Dairy Sci. 68:462-465.

Peters, R. R., S. Komaragiri, M. J. Paape, and L. W. Douglass. 2000 Evaluation of $1.6 \%$ phenol as a premilking and postmilking teat dip in preventing new bovine intramammary infections. J. Dairy Sci. 83:1750-1757.
Philpot, W. N., R. L. Boddie, and J. W. Pankey. 1978. Hygiene in the prevention of udder infections. IV. Evaluation of teat dips with excised cows' teats. J. Dairy Sci. 61:950-955.

Piessens, V., S. De Vliegher, B. Verbist, G. Braem, A. Van Nuffel, L. De Vuyst, M. Heyndrickx, and E. Van Coillie. 2012. Characterization of coagulase-negative staphylococcus species from cows' milk and environment based on bap, icaA, and mecA genes and phenotypic susceptibility to antimicrobials and teat dips. J. Dairy Sci. 95:7027-7038.

Quirk, T. E., L. K. Fox, D. D. Hancock, J. Capper, J. Wenz, and J. Park. 2012. Intramammary infections and teat canal colonization with coagulase-negative staphylococci after postmilking teat disinfection: Species-specific responses. J. Dairy Sci. 95:1906-1912.

Rasmussen, M. D., D. M. Galton, and L. G. Petersson. 1991. Effects of premilking teat preparation on spores of anaerobes, bacteria, and iodine residues in milk. J. Dairy Sci. 74:2472-2478.

Remington, J., D. Troy, and P. Beringer. 2006. Remington: The science and practice of pharmacy. Page 376. 21st ed. Lippincott Williams \& Wilkins, Philadelphia, PA.

Reneau, J. 2001. Prepping cows: Who needs it. Pages 33-42 in NMCPDPW Milk Quality Conference Proceedings. Natl. Mastitis Council Inc., Madison, WI.

Saxton, A. M. 1998. A macro for converting mean separation output to letter groupings in Proc Mixed. Pages 1243-1246 in Proc. 23rd SAS Users Group Int. SAS Institute Inc., Cary, NC.

Schmidt, A. L., S. P. Oliver, and M. E. Fydenkevez. 1984. Evaluation of experimental teat dip containing sodium chlorite and lactic acid by excised teat assay. J. Dairy Sci. 67:3075-3080.

Schmidt, A. L., S. P. Oliver, and M. E. Fydenkevez. 1985. Germicidal persistence of teat dips by modified excised teat procedure. J. Dairy Sci. 68:158-162.

Schuring, N. 2007. Obtaining management objectives through parlor time studies. Annu. Meet. Pages 3-11 in Natl. Mastitis Council 2007 Natl. Mtg. Proc., Natl. Mastitis Council Inc., San Antonio, TX. Natl. Mastitis Council Inc., Madison, WI.

Smith, J. F., D. V. Armstrong, M. J. Gamroth, and J. G. Martin 1997. Planning the milking center in expanding dairies. J. Dairy Sci. 80:1866-1871.

USDA-APHIS. 2008. Dairy 2007-Part III: Reference of dairy cattle health and management practices in the United States, 2007. APHIS National Animal Health Monitoring Systems, Fort Collins, $\mathrm{CO}$

USDA-ERS. 2006. Changes in the Size and Location of U.S. Dairy Farms. Pages 2-4 in Profits, Costs, and the Changing Structure of Dairy Farming/ERR-47. J. M. MacDonald, E. J. O'Donoghue, W. D. McBride, R. F. Nehring, C. L. Sandretto, and R. Mosheim. Washington, DC.

VanBaale, M., J. Smith, D. Armstrong, and J. Harner. 2004. Making decisions regarding the balance between milk quality, udder health, and parlor throughput. Univ. Arizona Coop. Ext., Tucson. 